\title{
Narradores: vozes e poderes de diferentes pensadores
}

\author{
Nancy Alessio Magalhães*
}

EM VÁRIOS MOMENTOS DE MINHA VIDA, tenho me visto em meio a observações paradoxais, tais como: "Seja mais objetiva, menos detalhista, não se desvie do assunto, vá direto ao ponto!" E também: "Pare de descrever a situação e conte-me logo o que aconteceu!" Ou ainda: "Ah! Como é bom ouvi-la, porque você é uma contadora de histórias!”.

Lanço-me em várias direções, quando reflito sobre estas questões, até porque, volta e meia, seja no nosso cotidiano diário, seja no cumprimento de nossos deveres de ofício, temos que expor ou resolver problemas em segundos; exercitar rituais de avaliação em poucos minutos. Mas, o que têm a ver essas questões com a interação de experiências que venho buscando - com o grupo de que faço parte - nos trabalhos de pesquisa, ensino e extensão em que lidamos com a oralidade e a imagem?

Comecei a perceber que minhas tarefas profissionais parecem me remeter a uma atualização de marcas do passado, às memórias que elas me fazem reviver.

Cresci convivendo intensamente com atividades artesanais maternas e paternas: minha mãe, exímia costureira e cozinheira e meu pai, marceneiro, artesão de ofício, depois rebelde operário da indústria

* Professora da Universidade de Brasília (UnB). 
moveleira e, posteriormente, desenhista projetista auto-didata. Aprendi com minha mãe, meus tios, tias e primos a alegria e o prazer das "suspensões do tempo do relógio", dos dias rituais de almoços e festas em família, do intercambiar infinito de afetos e experiências, respeito pelas matérias que se transformam em bordados, roupas, comidas, doces, malhas de lã, histórias. Com meu pai, de certo modo com meu irmão, o desafio de enfrentar o seu arraigado patriarcalismo, sem rancores; o orgulho de esculpir pacientemente e vencer a solidez de matérias como a madeira, o trabalho como expressão de dignidade humana, o gosto pela politização do debate de questões de nossa sociedade.

Minha mãe, muito religiosa, falava pouco, mas também me transmitia conselhos em aberto, seu gosto estético, seu prazer pela leitura, pelo virtuosismo em qualquer tarefa, sua esperança em meus estudos... Meu pai, ao contrário, agnóstico, gostava de expor oralmente suas idéias, como se estivesse respondendo a perguntas, com explicações e definições detalhadas, fosse qual fosse a situação ou o problema abordado.

Um certo mergulho nesses paradoxos parece-me fértil para discutir algumas problemáticas que o tema das vozes e poderes dos narradores faz aflorar em nossas experiências de pesquisa, onde através de uma prática dialógica, sujeitos comuns e anônimos, oprimidos, ao serem trazidos para a cena histórica, através de suas memórias, mostram que preservam outros poderes, rompem com vários silêncios do passado e do presente. No caso, tratarei aqui de relatos de entrevistados que abrem para a reflexão de que a pertinência a uma cultura e o direito à memória e à história incluem-se nas relações de sujeitos com a construção histórica de espaços rurais e urbanos, que concebem a experiência como legado imemorial, transcendente, como excesso de significações.

Nos projetos desses sujeitos, na sua humanidade, reside a vitalidade de suas tradições em constante reelaboração, na construção de direitos no presente, tarefa inconclusa. Então, a continuidade dessas tradições é dimensão de luta e dignidade, diante desses enfrentamentos ${ }^{1}$.

Conferir Magalhães, 1999, p. 1127-39. Entre outros trabalhos publicados, embora não necessariamente com as mesmas perspectivas da experiência de pesquisa abordada neste artigo, podem ser consultados: Amado (1993); Demartini (1996); Frisch (2000); Gomes (1999); Le Ven (1998); Lucena (1999); Montenegro (1992), Santana (1998) e Simson (1996). 
Nos dias de hoje, limiares dos anos 2000, a virtualidade, o domínio das imagens eletrônicas pareceria confirmar que a arte de narrar está muito próxima da extinção, como teria previsto Walter Benjamin, na década de 1930, em seu ensaio acerca do narrador. Pretendo introduzir algumas sutilezas em tal hipótese, buscando entender como mesmo para Benjamin, a arte de narrar ainda persiste no presente, mas como outra, não como eterno retorno, que, assim, seria repetição mecânica e vazia. "Só perece a imagem do passado que não é reconhecida como visada pelo presente..." (Matos, 1989, p. 57).

Por isto Benjamin coloca, logo no início de seu ensaio O narrador: considerações sobre a obra de Nikolai Leskov: "Por mais familiar que seja seu nome, o narrador não está de fato presente entre nós, em sua atualidade viva. Ele é algo de distante, e que se distancia ainda mais. Descrever um Leskov como narrador não significa trazê-lo mais perto de nós, e sim, pelo contrário, aumentar a distância que nos separa dele" (Benjamin, 1987, p. 197). É neste viés que podemos entender como nosso presente ainda pode conter esse narrador do passado, como outro.

O narrador é, deste modo, imaginado como alguém que vem de longe mas também que escuta com prazer o homem que conhece tradições e histórias de seu próprio país. Segundo Benjamim, camponeses e marujos comerciantes foram os primeiros nesta arte; no corporativismo medieval, aprendizes migrantes e mestres sedentários foram artífices que a aperfeiçoaram.

O que Benjamin ressalta é que não existem dadas condições, no contexto social da sociedade industrializada moderna, que permitiriam a realização de transmissão da experiência no seu sentido pleno, tais como: comunidade de vida e de discurso entre o narrador e o ouvinte; organização comunitária artesanal do trabalho; lenta acumulação de várias narrações sucessivas; progressiva sedimentação de diversas experiências; palavra unificadora; senso prático, utilitário da narrativa tradicional.

Então, a arte de contar da narrativa tradicional torna-se cada vez mais rara: aquela sabedoria, a verdade épica, o extraordinário, aquilo que não se entrega, que "conserva suas forças e depois de muito tempo ainda é capaz de se desenvolver", que "se assemelha a essas sementes de trigo que durante milhares de anos ficaram fechadas hermeticamente nas câmaras das pirâmides e que conservam até hoje suas forças 
germinativas" (Benjamin, 1987, p. 204). Aquilo que não é um relatório ou uma informação, como no caso de "ir direto ao ponto". Aquilo que é uma forma artesanal de comunicação, na qual o narrador mergulha o que quer narrar na sua própria vida, para dela poder retirá-lo; onde descreve as circunstâncias em que foi informado do que vai contar; onde "se imprime na narrativa a marca do narrador, como a mão do oleiro na argila do vaso".

Esse tipo de narração, então, não é produto exclusivo da voz; a mão, os gestos aprendidos na experiência do trabalho intervêm decisivamente. "A antiga coordenação da alma, do olhar e da mão, que transparece nas palavras de Valéry, é típica do artesão, e é ela que encontramos sempre, onde quer que a arte de narrar seja praticada" (Idem, p. 205, 221). Qual o papel da mão, do olhar, da alma no trabalho e na narração, hoje?

Sabendo narrar porque assimila à sua substância aquilo que ouve dizer, aquela dignidade de poder contar uma vida por inteiro, o narrador figura entre os mestres e os sábios. Naquela narrativa tradicional, narrador e ouvinte estão inseridos num fluxo narrativo comum e vivo, já que a história continua, aberta ao fazer junto, a outras propostas. Nesse fluxo, aquele que conta transmite um saber, do qual quem ouve pode tirar um proveito, uma sapiência prática, que pode tomar a forma de um produto sólido e único, de uma moral, de uma norma de vida, de uma advertência, de um provérbio, de um conselho. "Ora, diz Benjamin, o conselho não consiste em intervir do exterior na vida de outrem, como interpretamos muitas vezes, mas em 'fazer uma sugestão sobre a continuação de uma história que está sendo narrada" (Gagnebin, 1987, p. 11). Assim como "provérbios são ruínas de antigas narrativas, nas quais a moral da história abraça um acontecimento, como a hera abraça um muro" (Benjamin, 1987, p. 221).

É por tudo isso que, muitas vezes, quando nos deparamos com esses saberes, quase sempre não discernimos o que com eles podemos fazer ou como deles usufruir. Se não somos receptivos a conselhos, é porque não sabemos dá-los, nem a nós mesmos. Não conseguimos verbalizar nossa própria situação, não conseguimos contar nossa própria experiência ou a relatada pelos outros, incorporando-as às nossas próprias. As experiências estão deixando de ser comunicáveis. Entretanto, o próprio Benjamin, dialeticamente ressalta: 
"A arte de narrar está definhando porque a sabedoria - o lado épico da verdade - está em extinção. Porém, esse processo vem de longe. Nada seria mais tolo que ver nele um 'sintoma de decadência' ou uma característica 'moderna'. Na realidade, esse processo que expulsa gradualmente a narrativa da esfera do discurso vivo e ao mesmo tempo dá uma nova beleza ao que está desaparecendo, tem se desenvolvido concomitantemente com toda uma evolução secular das forças produtivas". (1987, p. 201, grifos meus).

Se para esse filósofo o indício dessa evolução, no início do período moderno, é o surgimento do romance e a invenção da imprensa, particularmente do livro, também para ele, ao mesmo tempo, a musa do romance já pode ser pressentida na poesia épica, nas invocações solenes das musas, que abrem os poemas homéricos.

"Mnemosyne, deusa da reminiscência, era para os gregos a musa da poesia épica. Esse nome chama a atenção para uma decisiva guinada histórica. Se o registro escrito do que foi contido pela reminiscência - a historiografia - representa uma zona de indiferenciação criadora com relação às várias formas épicas... sua forma mais antiga, a epopéia propriamente dita, contém em si, por uma espécie de indiferenciação, a narrativa e o romance... Em outras palavras, a rememoração, musa do romance, surge ao lado da memória, musa da narrativa, depois que a desagregação da poesia épica apagou a unidade de sua origem comum na reminiscência" (Idem, p. 211).

A reminiscência funda a cadeia da tradição de transmissão dos acontecimentos, de geração a geração. Ela corresponde à musa épica no sentido mais amplo e inclui todas as variedades da forma épica, entre elas a encarnada pelo narrador, como os orientais, que tecem a rede constituída por todas as histórias entre si, imaginando uma nova história em cada passagem que estão contando.

Então, já se prenuncia, nesses poemas homéricos, o contraste da memória perpetuadora do romancista, consagrada a um herói, a um 
combate, uma peregrinação, com a breve memória do narrador, de muitos fatos difusos, que trabalha artesanalmente a sua matéria, a vida humana, sua experiência e a dos outros.

Também se prenuncia, na Grécia Antiga, o que vai ser um dos argumentos legitimadores do conceito moderno de história. É o que se refere à negação do passado como legado transcendente, como liberdade de se buscar nele possíveis leituras do sentido de nossa existência; de arrancarmos do tempo do relógio o devir que se estende a tudo o que vive no universo. Concepção que ao cristalizar o passado, como se fosse um produto final de um mero processo de fabricação, como "a mesa é, evidentemente, o produto final da atividade do carpinteiro" (Arendt, 1988, p. 113), esvazia-o de seu conteúdo, de suas significações humanas.

Existe um quadro de Velázquez (figura à direita), do século XVII, que se chama "As fiandeiras", o qual me causou profundo impacto, quando o vi no Museu do Prado, em Madri, não só pela sua beleza estética, e por ser, em geral considerado o primeiro quadro, na história da arte, dedicado ao tema do trabalho. No primeiro plano, mulheres em grupo fiando e, com destaque, ao fundo, em segundo plano, geometricamente composto pelo pintor, um pouco acima do primeiro, a representação da história de Atenas e Aracne. Os temas mitológicos em Velázquez carregam-se de cotidianidade, de pessoas comuns do contexto deste pintor, e esta cotidianidade, ao mesmo tempo, também se impregna, em suas pinturas, da solenidade em geral atribuída a esses temas (García, 1996, p. 84).

Atenas, Deusa grega inspiradora de todas as artes, do trabalho do espírito e da atividade inventiva da inteligência, era protetora de todos os ofícios exercidos pelos homens, mas, sobretudo industriosa artesã, que presidia os delicados trabalhos dos delgados dedos das mulheres, que se vangloriavam de ter aprendido a tecer com as suas lições. Mas, uma jovem lídia, Aracne, exímia na arte de urdir lãs em tecidos, considerava que não devia essa fama ao seu nascimento, nem à sua pátria, mas exclusivamente ao seu talento; negava que seu extraordinário ofício se devesse aos ensinamentos da Deusa. Resolveu competir com Atenas. Esta assumiu traços de velha e cobrindo a cabeça de cabelos brancos, apoiando os membros enfraquecidos num cajado, disse a Aracne: 


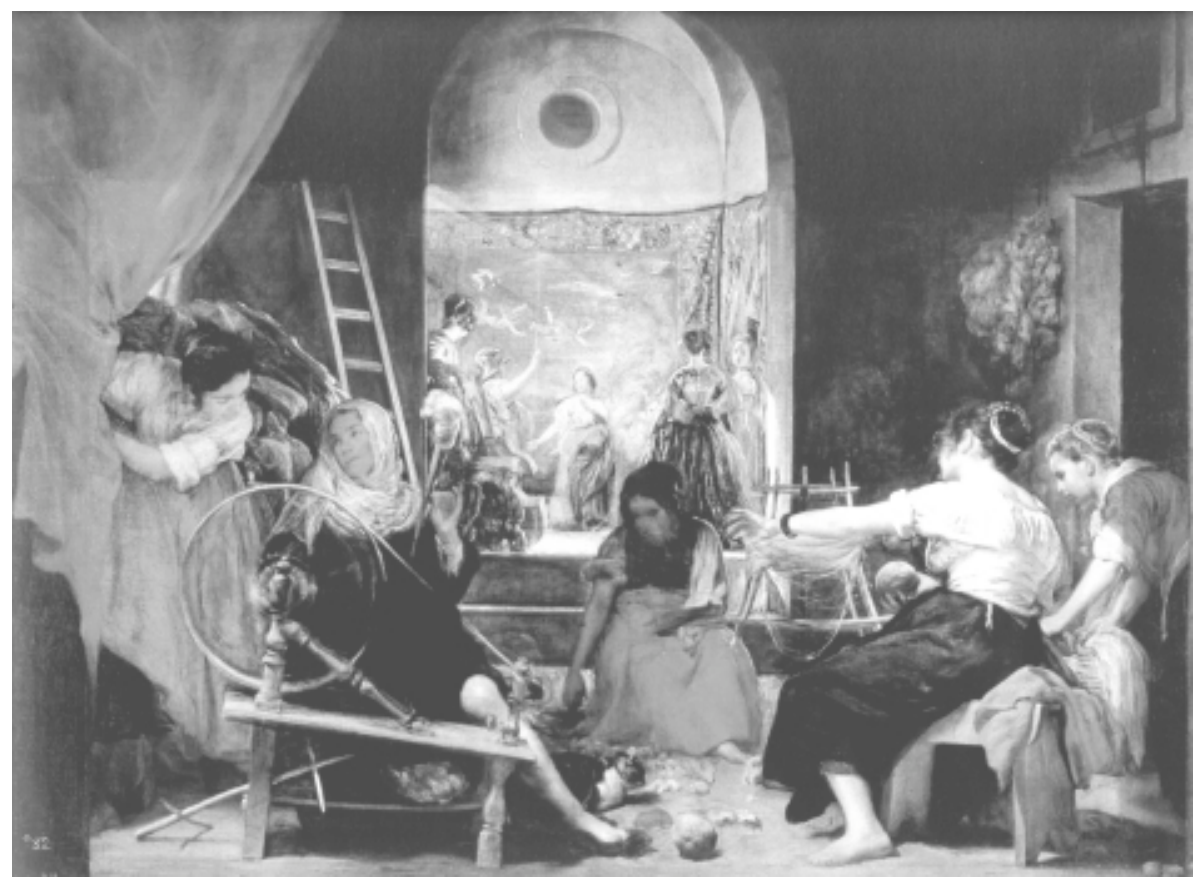

"A velhice, minha filha, não traz com ela males apenas: a experiência é fruto tardio da idade avançada. Não desdenhes meus conselhos. Podes pretender a glória de sobrepujar todos os mortais, mas não poderás, como sustentas, suplantar os trabalhos de u’a mão imortal...” (Meunier, 1975, p. 28).

Atenas despojou-se dos traços da velhice e as duas começaram a tecer, infatigavelmente, com o desejo de vencer. Atenas não encontrou o menor defeito no trabalho de Aracne; despeitada, rasgou-o. Aracne, não suportando a afronta, tentou enforcar-se. Mas Atenas tirou-a da morte e a transformou em aranha, cuja vida passou, daí em diante, a ser eternamente suspensa a um fio, enredado na mesma e repetida trama.

Aí está previsto e representado, já na Antiguidade, o processo de naturalizar a história, processo de identificação com o passado como cristalizado, como o mesmo, como eterna repetição; o processo de tecer e transformar o que seria uma das possibilidades da história na própria bistória, pela exclusão da transcendência, de um legado coletivo, que está acima de nós, de excessos de significação, que permanecem como 
valores, como referências que dependem de uns, e também de outros, nas suas possibilidades de reconstrução, sempre em aberto.

Assim, podemos provocar um estado de semelhanças entre essa antiguidade grega e o relato de Seu Arcelino Rodrigues do Amaral, nascido no Rio Grande do Sul, em Guarantã do Norte (MT), na época com 73 anos, hoje já falecido, que nos disse numa entrevista, em vídeo, em 1987, sobre a transcendência coletiva de um legado como a terra:

"Como falemo já hoje, a respeito do rosário, o Menino Jesus foi ordenado pelo Anjo pra avisar à Maria - anunciar - que ela ia ganhar esse filho pra salvar o mundo. E ficou a ordena do rosário, que foi ordenado por ela e por ele. E esse rosário, achavam difícil como é que ia ficar.

Das lágrimas de Santa Maria nasceu um capim e esse capim deu uma frutinha e essa frutinha que foi feito o rosário. E essa cruz, que Jesus foi crucificado, então ficou a cruzinha no rosário pra (a)provar como é que o mundo tá sendo atendido pra ser salvo. Já há muitos anos que o povo vem rezando com o rosário, defendendo muitas espécie de mal que já ameaçou e outros vieram, mas foi escapado. E esse rosário, e essa santinha, uma vez que tem no rosário, nunca nós devemos de abandonar! Nós devemos de usar! Que aqui nós usemo. A santinha vem de casa em casa pra que nós rezemo o rosário. E tem aqueles que não acreditavam, não vêm, não assistem. Então aqueles, eles estão fora, aqueles estão a perigo pra alguma coisa.

E o rosário, nós rezemo de noite e algumas horas do dia. Como, aqui vem gente: 'Eu hoje quero que reze um terço aqui'. E pedindo pra quê. Então, rezemo o rosário, com a santa cruz na mão. Sempre na Igreja, eu tenho rezado também com a cruz na mão. E temo que dar pro rosário e essas continhas de lágrimas de Santa Maria pra nos defender os mal que tá ameaçado e aproximado. Porque a promessa dos dois mil ano, ele, aqui, o mundo não se termina. Tá acontecendo as doenças importante que apareceu. Que existe lugar da terra, então essas pensava que tão sepultada, lacrada, pra não surgir outra doença daquela mesmo. Isso é importante. 
E isso tá acontecendo em outros países. Mas é um causo é ameaçado vir para cá. E nos países europeu, esse é um assunto que tem países que não aceita, não tem criança a mesma coisa como aqui, estimado. As mães estimando os filho. Essas lágrima de Santa Maria que a Santa Maria abençoa as crianças pra continuar o mundo. Então, ela (a)prova tudo. O dia 12 de outubro, a Nossa Senhora Aparecida é a nossa Santa Maria, que ela foi ordenada pro nosso país, ser a dona, governar! Então, esse dia as criança tão junto com ela. E as criança pra nós, pra estimação, elas são a chave do mundo!

As mães estimar os filhos e ter amor aos filhos. Ter amor assim como a Jesus, Santa Maria tinha amor em Jesus. Que ela sabia que ele ia ser crucificado, ia acontecer aquilo... Mas ela sentiu o filho, ela derramou as lágrimas, pra existir o amor aqui na terra, pra ficar o amor. A mãe querer bem os filhos, nenhuma mãe se deixar dos filho, procurar querer bem. Então, por isso que as mãe estima os filho, as mãe querem bem aos filhos, têm amor aos filho.

Porque Santa Maria deu essa ordem. E ela continua estimando Jesus, que tá perto com ela lá no céu. Mas eles tão olhando pra terra, tão enxergando o que é que acontece.

A terra é a vida da pessoa porque a alimentação sai da terra. Todos nós precisemo. $\mathrm{O}$ meu avô era um coronel na guerra do Paraguai e ele ganhou a guerra. Ele deixou um livro feito que da geração até a terceira geração dele, ganhava terra, ganhava aí uns quinhentos alqueires, mil. Mas depois, quando eu me interessei, de procurar ganhar a terra, já dependia do dinheiro, aí já era o dinheiro que mandava, aí eu não tinha, não ganhei. Essa aqui não tá no meu nome. Então, já dependeu foi do dinheiro. Não ganhei terra. E o meu avô deu, pros netos, pros filhos, netos. E ele foi um guerreiro, se chamava Raimundo Rodrigues do Amaral. Era um coronel.

É, a alimentação sai da terra, a alimentação sai da terra. $\mathrm{E}$ as criança têm que ser dominada por nós, os grande. Nós temos que ocupar a terra, se virar, que é apresentar... A gente tem que apresentar alimentação pras criança, tem que ter 
pra eles. E tem que sair da nossa mão, e a nossa mão tem que mexer com a terra pra alimentar as criança”".

Ele sugere que a vida levaria os adultos a servirem às crianças, apresentando-lhes o que obtêm quando trabalham a terra com as mãos para alimentá-las. Há, segundo ele, a necessidade de se acreditar naqueles que estão ordenados para cuidar do mundo: como a Santa Maria, que derramou suas lágrimas de mãe, que se transformaram em capim, o qual deu frutinhas, das quais é feito o rosário, que assim foi ordenado para as mães não esquecerem de ter amor aos filhos. O caráter sagrado da autoridade tanto de pai e mãe, nessa concepção, é garantido por seres divinos - Jesus e Maria -, mediadores de elementos da natureza, formadores das relações familiares. Que reflexões podem se abrir a partir dessas questões?

Elas se aproximam, entre outros, dos filósofos frankfurtianos, para quem a crise da família é de origem social; não é possível negá-la ou liquidá-la como simples sintoma de degeneração ou decadência. Nas sociedades industriais avançadas, parece estar sendo possível a concretização do que rigorosa teoria liberal havia concebido: a transformação de todos em átomos sociais. Há uma integração acrítica do indivíduo na sociedade. Tudo é substituível, inclusive os próprios indivíduos, num mundo onde a vida no mercado, agressiva e baseada na concorrência, na capacidade técnica e na eficiência, é encarada como fator decisivo. Assim, para esses filósofos, a crise da família refere-se à crise de desintegração da humanidade, com sua possível dissolução como coletividade, o que faz prever uma recaída na barbárie (Horkheimer \& Adorno, 1973, p. 132-50; Matos, 1993, p. 58).

A crise da família não é a abdicação da autoridade como tal; o problema é que esta se torna cada vez mais abstrata, por isso implacável e desumana, como indica o Sr. Arcelino. A família não é mais combatida, mas posta de lado, esquecida. O que mutila os indivíduos e impede a individuação não é a proibição familiar, mas a indiferença e a frieza.

Ao contrário, o olhar, ao mesmo tempo comovido e distanciado, é o olhar do memorioso, que se aproxima, roça e penetra os materiais da cultura, mas sem fazê-los perder sua intimidade, a atmosfera que os impregna, que toma esses materiais em sua distinção. Não é o olhar insolente, consumista, das coisas intercambiáveis, reduzidas às merca- 
dorias. É o olhar respeitoso e atento ao mais próximo como se viesse de longe, para descobrir mistérios, mensagens soterradas (Gonçalves Filho, 1988, p. 107; Benjamin, 1989, p. 212-3).

Como não lembrar aqui Seu Arcelino, quando fala na necessidade de trabalhar a terra com as mãos, apresentar alimentação para as crianças e, assim, estabelecer um domínio, um poder? No dia em que gravamos em vídeo com Seu Arcelino, ele estava muito emocionado e sua família temia que o coração já cansado lhe falhasse. Por isso, preocupamo-nos em não alongar sua entrevista, conscientes de que perderíamos muita riqueza no muito que ele teria a dizer (Magalhães, Nunes e Paiva-Chaves, 1997). Mas ele praticamente acabou se autodirigindo. Suas lágrimas - que o câmera não conseguiu gravar - não impediram que ele desse o recado que mais desejava: sua concepção do caráter sagrado da terra e do amor materno, para ele fundamentais na manutenção e reprodução da espécie humana. Através da terra, renasce a vida e, com ela se podem alimentar as crianças, a chave do mundo. Não se pode desfazer da terra, porque em cima dela se vive e se tem o que comer. Na cidade, vai arrancar comida de onde? Por isso, tem que se pensar bem antes de vender a terra. Tem que dar um valor tão grande à terra, que é um mistério da vida, que não dá nem para imaginar. Mesmo que ela tenha um preço, a terra nunca é bem paga, pelo que pode oferecer para todos nós.

Diante do esfacelamento do social e da experiência nos dias em que vivemos, há, então, um declínio da memória e da palavra comuns, o significado de nossas vidas não está mais dado implícita nem imediatamente pelo contexto social. É a partir do reconbecimento lúcido desta perda que a questão dos laços entre a experiência e a narrativa pode ser colocada, não para repetir o passado, pois isto seria assumir a incapacidade de enfrentar o presente, mas para acolher o passado como um outro, os seus legados no presente, principalmente seus elementos decretados negligenciáveis e fadados ao esquecimento, perdendo as diferenças temporais. Demorar-se apaixonadamente no presente para visá-lo como outro pelo passado, não para fazer apologia desse presente, mas para cavar trilhas do futuro (Matos, 1989, p. 97), é a tarefa que urge diante dos esquecimentos a que nos levam, entre outras, aquela perspectiva naturalizada da história, a que aludi anteriormente. 
$\mathrm{Na}$ perspectiva benjaminiana há um laço entre o enfraquecimento, pobreza e fracasso da experiência e o fim da arte tradicional de contar, no capitalismo moderno. A memória é, então, crucial como meio e processo para provocar, (re)construir as articulações entre presente e passado, entre o indivíduo e o social. Essa idéia de reconstrução da experiência deveria ser acompanhada por uma outra forma de narratividade, embora isto não esteja explicitado em Benjamin. Mas como explicitá-lo, se tratamos com um processo de busca? Esta dimensão Benjamin enfatizou em Proust, considerado por ele como um (não o único) "dos que reconheceram a impossibilidade da experiência tradicional na sociedade moderna e se recusaram a se contentar com a privaticidade da experiência vivida individual" (Gagnebin, 1987, p. 89, grifo meu).

Quando nos debruçamos nos desafios das leituras inesgotáveis dos seus textos, o que Benjamin parece exigir é a ampliação da concepção de experiência, contra seu uso redutor. Não será por isso que ele também se dedicou a interpretar os brinquedos infantis?

Construir a experiência, num universo incerto, a partir de fragmentos esparsos, destroços, tradições esfaceladas, pistas deixadas pelas histórias que não tiveram chance de acontecer, legados da grande tradição narrativa, então não significa recriar o calor de uma experiência coletiva, a partir de experiências vividas isoladamente. "Não existe mais uma totalidade de sentidos, mas somente trechos de histórias e de sonhos... indubitavelmente uma ameaça de destruição, mas também - e ao mesmo tempo - esperança e possibilidades de novas significações". Assim, a historiografia tem um princípio construtivista nas teses de Benjamin, que deve ser destacado para evitar a redução de sua teoria da experiência à sua dimensão romântica e nostálgica, presente, mas não exclusiva, no ensaio "O narrador" (Idem, p. 10).

Há, então, que provocar um estado de semelhança entre o presente e o passado e saber ler os sinais assim emitidos. As imagens do passado reluzem no presente e relampejam, porque o passado não está morto, inerte. Ambos se dão a conhecer, se o esforço que se fizer para esse reencontro reativado for bem sucedido. Então, isto não significa desenterrar o passado para apenas nele descobrir uma identidade perdida. Porque o mistério existe, no sentido de que esses sinais, muitas vezes, são difíceis de se captar e entender. 
Para a história constituir-se em experiências comunicáveis, nessa reconstrução através da memória, segundo Benjamin, o historiador deve ser capaz de identificar no passado os germes de uma outra história, capaz de levar em consideração os sofrimentos acumulados; ser um recolhedor de experiências, onde podem se combinar perspicácia, astúcia, insolência e ironia; de conteúdos utópicos, quando se dão como repetição do não realizado, como experiência do passado; de fazer junto uma história aberta a esperanças frustradas, "a becos sem saída, aos perdedores esquecidos”, a outras propostas (Thompson, 1987, p. 13).

Muito pertinente, a respeito desse papel do historiador, foi o depoimento de Dona Maria Albaniza Rebouças, após a projeção de nossos documentários historiográficos em vídeo, na Vila Planalto, em Brasília:

"Eu achei lindo, eu fiquei emocionada, porque eu não esperava que o trabalho tivesse ficado tão bonito, viu? $\mathrm{E}$ isso é de grande importância aqui pra nós. Isso vai ficar na nossa memória para sempre e para nossos filhos e netos... Porque isso é a nossa história, então isso vai ficar guardado dentro da gente para sempre... Mas se não fossem vocês procurarem nós, também nada tinha ajeitado, tudo ficava guardado aqui dentro da Vila Planalto" (Magalhães, Nunes \& Paiva-Chaves, 1997, p. 39).

Ainda recentemente, no debate do nosso projeto de pesquisa e extensão, do qual participa como moradora da Vila Planalto, Efigênia Fernandes Dias, referindo-se ao livro com relatos dos moradores dessa Vila e do Paranoá-DF, lançado conosco naquele dia, afirmou que "a história de Brasília estava dentro da minha casa e eu não sabia” (Magalhães \& Sinoti, 2001).

Quando fomos também, ao Paranoá, avaliar com Dona Josefa Pereira das Neves e Seu Ataíde Pereira das Neves seus relatos nesse mesmo livro, ela nos disse: "Veio um pesquisador, aqui, com o pessoal da Administração Regional do Paranoá, querendo nos entrevistar. Nós dissemos pra eles que já temos nossas entrevistadoras". Seu Ataíde, então, completou: "Porque vocês entram na nossa cozinha e bebem água e café no copo de requeijão, eles não”. Pareciam se referir a certa 
relação de confiança mútua, de horizontalidade, mesmo que temporária, que para eles é possível escolher, construir e estabelecer conosco, na e através da realização desse trabalho, apesar da sempre explicitada diferença de poderes e de papéis, o que não viam como possível na outra situação.

Esses momentos de (re)-construção de experiências comunicáveis, entre passado e presente, são únicos e podem se perder, caso não tenhamos possibilidades de captá-los, percebê-los e interpretá-los como possibilidades de comunicação em aberto. A respeito, já discutimos o trabalho de feitura das entrevistas orais como construção, mesmo que temporária, de uma communitas entre entrevistados e entrevistadores (Magalhães \& Litiwinczik, 2000).

Benjamin acentua que há um movimento infinito na memória popular, na narrativa tradicional: cada história puxando uma outra história, que traz uma outra... Quando constituímos os relatos em nossas experiências de pesquisa, seja nas próprias realizações das entrevistas, na costura dos trechos transcritos, na feitura de textos de livros ou na edição dos documentários em vídeo, por exemplo, essa dinâmica ilimitada é a do relato, cada texto suscitando, desencadeando outro texto. Dessa forma, incluímos, na Série Em cima da terra, e depois em minha tese de Doutorado, José Baiano Alves dos Santos, colono em Guarantã do Norte-MT, entrevistado em vídeo, em 1987, por José Walter Nunes. José Baiano interpreta a questão do direito à terra, concebida também como sagrada, e elabora uma metáfora sobre a reforma agrária no Brasil, ampliando o tema indiretamente suscitado por Seu Arcelino. A terra, então, é a plenitude, é o que há de melhor, de mais fundamental para a geração e o sustento da vida, é a própria vida. Sem ela, nenhum ser vivo pode viver. É sagrada, é um direito de todos, diz José Baiano. Direito que está interditado por uma "lesma paralítica", fina imagem de crítica perspicaz à reforma agrária proposta pelo governo:

"Olha, a terra pra mim representa tudo em minha vida, porque sem a terra é impossível qualquer um ser humano viver. Não só o ser humano, mas todos seres, todos os seres vivos da face da terra, ninguém sobrevive sem a terra... Então, por ela ser dom de Deus e ela ser feita pra todos, é por isso que existe essa paixão de todos nós, de todo mundo que 
você vê por aí, em busca dessa terra. Porque essa terra, nós quando ganha uma terra... Ganha não! Nós quando recebe, porque a terra é nossa! Então, só falta todos nós receber! Então, nós quando recebe essa terra, então nós tamos sendo liberto, da escravidão, da unha daqueles que já têm terra!

Olha, esse problema da reforma agrária, atualmente, ela quase, ela só foi só no papel! Ela, essa reforma agrária aí, ela vem andando que nem lesma paralítica. Vem andando que nem lesma paralítica, porque se o governo se interessasse mais, e se colocasse pessoas interessado pelo povo, trabalhar pelo povo, que está sem terra pra colocar, eu acredito que não estava tendo todo esse problema que nem nós estamos vendo aí, de pessoas atrás de terra, eu acredito que ao menos setenta por cento desse pessoal que estão aí no Brasil já estaria, já tinha sido colocado nessas terras.

Porque nós temos um Brasil aí, que é um grande continente. E se esses setenta por cento desse povo que eles estão sem terra, aí, estivesse sendo, tivesse sido assentado, já estivesse trabalhando nessas terras, o nosso país hoje também seria outro. Porque é uma vergonha pra nós brasileiros, torno a falar novamente pra vocês. Nós, num país de terra tão fértil e de tanta terra improdutiva aí, nós ter pessoas morrendo de fome, isso é uma vergonha para os nossos administradores!

E no dia que ele recebe um pedaço de terra, que nem eu tenho aqui hoje, ele torna-se liberto. Porque, aí, ele não tem aquela preocupação de hoje, dele tá aqui hoje, que nem nós já estamos aqui, que nem eu estou aqui hoje, e amanhã pensando pra onde eu vou. Eu tenho uma morada fixa, eu tenho um chão firme pra mim pisar! Eu tenho um chão aonde eu sei que ali eu posso trabalhar! Então, é por isso que é o desejo de todo mundo é ter esse pedaço de chão pra trabalhar, pra cultivar para ali produzir e cuidar de seus filhos, da sua família!”

Esses vestígios da cultura e da história, que ainda são patrimônio desses sujeitos, suporte destas suas memórias e histórias, fazem lembrar e aproximam-se de profundos questionamentos a respeito formulados por Arendt (1987, p. 10) 
'Devem a emancipação e a secularização da era moderna, que tiveram início com um afastamento, não necessariamente de Deus, mas de um deus que era pai dos homens no céu, terminar com um repúdio ainda mais funesto de uma terra que era a Mãe de todos os seres vivos sob o firmamento?

A Terra é a própria quintessência da condição humana e, ao que sabemos, sua natureza pode ser singular no universo, a única capaz de oferecer aos seres humanos um habitat no qual eles podem mover-se e respirar sem esforço nem artifício. O mundo - artifício humano - separa a existência do homem de todo ambiente meramente animal; mas a vida, em si, permanece fora desse mundo artificial, e através da vida, o homem permanece ligado a todos os outros organismos vivos..."

Prosseguindo, esta filósofa não desconhece, neste trabalho editado em 1958, que a ciência vem buscando tornar "artificial" a própria vida, desejando trocar um dom gratuito por algo feito pelo próprio ser humano. Significativamente, alerta-nos "Não há razão para duvidar que sejamos capazes de realizar essa troca, tal como não há motivo para duvidar de nossa atual capacidade de destruir toda vida orgânica da Terra. A questão é apenas se desejamos usar nessa direção nosso novo conhecimento científico e técnico - e esta questão não pode ser resolvida por meios científicos: é uma questão política de primeira grandeza, e, portanto não deve ser decidida por cientistas profissionais nem por políticos profissionais". Enfim, uma decisão de responsabilidade de todos seres humanos, que atinge de perto o futuro de outras gerações (Magalhães, 1996).

Há lutas, então, que se desenvolvem entre projetos alternativos de organizar a sociedade. Interessa-nos explicitar mais o que exprimem aqueles sujeitos que foram silenciados pela memória dominante, excluídos da cena histórica, escrita e visual, suas experiências, perspectivas, visões de mundo, sobretudo percepções de temas, problemas e questões, ainda enfrentados, não resolvidos no mundo de hoje. Fazer transparecer, mais e mais, sensações de perda, necessidades de reconstrução e sobrevivência, no cotidiano do quase imperceptível exercício de poderes, do poder que existe em ser assim e agir assim. Para, então, entendermos 
como esse exercício se faz e se refaz, por exemplo, na experiência da migração e no permanente trabalho de recriação e de negociação dos fundamentos de relações de homens e mulheres entre si e com a terra, com a cidade, de seus princípios de conduta interativa, com a mesma categoria de pessoas e com outras categorias, feixe intricado de crenças, sentimentos e valores.

Neste ponto, é interessante recorrer a Foucault (1988), que ao longo de sua obra investigou procedimentos de poder usados para controle do corpo, dos gestos, atitudes, comportamentos, hábitos, discursos, que incitam produtividades (e não só repressão, exclusão, recalque, censura, mascaramento). Em vários e diferentes pontos e níveis da rede social são exercidos poderes moleculares, capilares, esparramados, que podem se transformar, ligados ou não às mudanças no aparelho do Estado. Este, como nível mais geral do poder constituído, exerce um controle que não é suficiente para fazer desaparecer ou transformar essa rede de poderes enraizada numa sociedade. O poder se exerce e se disputa, é relacional, existe em práticas: é luta, relação de força, situação estratégica. Não é um lugar que se ocupa, nem um objeto que se possui como uma mercadoria. Tem positividade, produz objetos e rituais.

Foucault também situou a arqueologia como uma história dos saberes. $\mathrm{Na}$ investigação dos saberes, pretendia explicar como eles se transformam, considerando-os como materialidades, práticas e acontecimentos, elementos de um dispositivo de natureza estratégica, isto é, de um dispositivo político, remetendo-os a relações de poder que os constituem.

Nos saberes dominados acentua os saberes que ficaram sem vida, sepultados, mascarados por lutas e confrontos, que a crítica faz reaparecer pela erudição. Nesse âmbito, também considera dominados os saberes desqualificados como incompetentes, inferiores, abaixo do nível requerido de conhecimento ou cientificidade. Não é uma recusa a métodos, conteúdos e conceitos de uma ciência; mas sim uma oposição aos poderes centralizadores da instituição e do funcionamento do discurso científico. A crítica efetua-se através de um "retorno de saberes" e essas duas formas de saberes dominados - eruditos e das pessoas são acopladas e, assim, re-des-cobertas as lutas e memórias dessas lutas.

É nesta perspectiva que desejo realçar o caráter educativo que pode assumir uma pesquisa, na universidade, quando a ela se articula a 
dimensão de extensão de conhecimentos, numa alternativa de produção de saberes, de aprendizado mútuo entre professores, alunos, técnicos e grupos da sociedade. Nessa alternativa aquele "retorno de saberes" se faz crítico, quando se luta para construir, na prática, uma relação transformadora, oportuna e estratégica entre esses agentes sociais, no sentido de tornar visíveis, des-cobrir, saberes e poderes cobertos por interpretações de si, dos outros, pelas escolhas, sempre sociais, do que é representativo para si e para o grupo.

Assim, o que está coberto em espaços comemorativos, como 21 de abril de 2000, por exemplo, (Magalhães, 2000), pelo endosso dos poderes dominantes centralizadores, pode ser des-coberto através, entre outros, de processos de pesquisa e extensão, em que se assume um caráter de construção dialógica nunca definitiva, sempre inacabada, entre pesquisados e pesquisadores. Como é nosso caso, em que projetos prévios são redesenhados e reescritos a partir desse diálogo entre esses diferentes atores da sociedade, o que os transforma e os evidencia também como diferentes pensadores (Gramsci, 1989). Nesta direção, é que temos experimentado os recursos da história oral, do registro fotográfico e em vídeo como opções metodológicas de acesso às narrativas orais, corporais e faciais e às múltiplas dimensões do cotidiano desses grupos sociais.

Um outro aspecto dessa dinâmica, desse movimento da memória, é a possibilidade de abertura, saber contar sem dar explicações definitivas, com uma certa sobriedade nesse ato de explicar, o que Benjamin (1987, p. 203-4) identifica na força do relato de Heródoto: a escritura da história disponível a várias interpretações, uma continuação, que no futuro outras leituras, outras reflexões renovarão. O historiador escreve a história, sendo obrigado a explicar, de um ou outro modo, os episódios com os quais lida, sua singularidade, os excessos de significação de que são portadores esses episódios. O cronista narra-os em sua literalidade, representando esses episódios como modelos da história do mundo. Para Matos (1989, p. 57), no horizonte benjaminiano, não existe diferença entre história e memória, mas entre o historiógrafo e o cronista. Assim, a escritura da história pode se enraizar na narração, na arte e no prazer de contar, principalmente pela inserção dos fatos no fluxo insondável das coisas, "sem distinguir entre os grandes e os pequenos", como o cronista que "leva em conta a 
verdade de que nada do que um dia aconteceu pode ser considerado perdido para a história" (Benjamin, 1987, p. 223).

Em minha tese de Doutorado eu já havia intitulado dois capítulos de urdiduras e tramas. Desse tempo até hoje, "muita água rolou embaixo da ponte" e, assim, num esforço de reflexão, através da experiência, tento inserir outras sutilezas nesta questão, tão cara ao nosso ofício de historiadores. Urdidura, metáfora apropriada no sentido do conjunto de fios preparatórios da trama, que vão sendo dispostos para que entre eles passem os outros fios da memória e da história. Urdidura, o esquecimento (no sentido grego, o que está oculto) é o que está ainda latente, apelos do passado no presente que ainda não foram captados, reconhecidos. Benjamin (Idem, p. 37) interroga-nos se não seria o trabalho de rememoração espontânea de Proust, sua memória involuntária, "o trabalho de Penélope do esquecimento... o oposto do trabalho de Penélope, mais que sua cópia? Pois aqui é o dia que desfaz o trabalho da noite. Cada manhã, ao acordarmos, em geral fracos e apenas semiconscientes, seguramos em nossas mãos apenas algumas franjas da tapeçaria da existência vivida, tal como o esquecimento as teceu para nós. Cada dia com suas ações intencionais e, mais ainda, com suas reminiscências intencionais, desfaz os fios, os ornamentos do olvido". Então, a bistória constitui-se de memória, constitui-se de experiências comunicáveis, como possibilidade de outras significações, tecida com o esquecimento e a recordação. Assim, a trama, recordação, lembrança é uma relação deliberada com o passado. "Os fatos não existem isoladamente, nesse sentido de que o tecido da história é o que chamamos de trama, de uma mistura muito humana e muito pouco 'científica' de causas materiais, de fins e de acasos; de um corte de vida que o historiador tomou, segundo sua conveniência, em que os fatos têm seus laços e sua importância relativa... Essa trama não se organiza, necessariamente, em uma seqüência cronológica: como um drama interior, ela pode passar de um plano para outro..." (Veyne, 1992, p. 28).

A história, constituída de memória, é urdidura e é trama, é tecido do esquecimento e da lembrança, é passado e presente, pois, nesse ato de tecer, conseguimos ou não revelar semelhanças entre passado e presente, sintetizadas num texto - para os romanos, aquilo que se tece. Porque se formos buscar o significado de revelação, qual seja, o processo de tornar visivel uma imagem latente, podemos sustentar que a palavra, o objeto, a 
imagem visual, o texto, enfim, velam e revelam. A urdidura e a trama têm permanências que não são permanências, continuidades que não são continuidades, porque são latências; pois o passado, não é mantido, é transformado numa outra forma, para não desaparecer no esquecimento; o presente também é transformado, porque revela a possível realização de apelos negligenciados do passado, caso consigamos captá-los. Esses apelos ainda podem se perder, se não forem lidos ou percebidos nas linhas do atual.

A semelhança profunda entre presente e passado, a presença do passado no presente e o presente que já está lá, prefigurado no passado, é muito mais forte do que o tempo que se esvai sem que possamos retê-lo. Assim, Proust não escreve "memórias", "busca" analogias e semelhanças entre o passado e o presente; não relembra simplesmente os acontecimentos, não é um memorialista. Para ele, podemos subtrair os acontecimentos das contingências do tempo através da metáfora. (Gagnebin, 1987, p. 15-16). Sabemos que a metáfora é um tropo; como um tropo, é um desvio (para os gregos) de linguagem e, assim, também do tempo. Deste modo, "“a memorialização', a memória eternizadora é distinta da 'memória épica', entretenedora, própria do contador de histórias” (Matos, 1989, p. 58).

O discurso fundador sobre Brasília, em geral, pretende eternizála como se ela tivesse surgido do nada, de espaços vazios e inabitados. Sua implantação como símbolo da modernidade se teria dado num espaço estigmatizado como decadente e atrasado. Durante nossos trabalhos de pesquisa e extensão, tecemos relatos com trabalhadores, moradores da Vila Planalto - local remanescente de acampamentos de empresas construtoras -, que, de algum modo, endossam terem erguido Brasília onde nada existia, mas, neste caso, estimulados pelos desafios da aventura e para se legitimarem e se incluírem na história de feitos pela construção desta cidade, na sua epopéia. Entre outros, diz Seu Gabriel Balbino Nogueira, eletricista e apontador, já falecido, entrevistado em vídeo por José Walter Nunes e Marta Litwinczik Sinoti, em 1993:

"Eu cheguei em grupo, inclusive nós pegamos um avião... Pegamos o avião no aeroporto da Pampulha, descemos em Anápolis, ficamos um bocado de dias em Anápolis. De Anápolis pra cá nós gastamos 12 horas de viagem, não tinha 
estradas aqui em Brasília, não tinha nada. Só tinha ema, lobo, mutum, cobra, não tinha nada, só ema e cerrado. Só existia o cerrado e o céu, o céu azul e mais nada!"

E também Sr. Cabeça (Antônio Amâncio Filho), operário aposentado e agricultor, entrevistado em vídeo por mim e por Isabella B. Ferreira, em 1993:

"A gente ficou do dia 17 até o dia 21, lá dentro do Congresso sem poder sair. Trabalhando, comia, vivia, bebia, tudo ali dentro, porque tinha que inaugurar de qualquer forma. Então, quando foi no dia 21 que fez a inauguração, a coisa mais linda que eu já pude ver na minha vida mais não tinha... hora eu assistia, horas eu perdia porque aquela coisa fugia da mente, esclarecia assim. Mas até que enfim a noite isso foi a claridade de fogos mais bonito que eu já pude ver na minha vida e todo tipo de gente que saiu dessa inauguração de Brasília. Aí, deu gosto da gente ver aquilo!"

Com a continuidade desses trabalhos, começamos a elucidar como se deu a articulação entre a proposta de modernidade dessa cidade e o modo de vida tradicional de trabalhadores e goianos, tema que permaneceria no esquecimento, sob ameaça de ser perdido para a história, caso essas experiências latentes não fossem registradas. À medida que fomos realizando essas entrevistas no Pananoá, verificamos que para muitos era mais importante ressaltar que as relações com os goianos, moradores da região antes da construção de Brasília, também fazem parte da experiência da construção civil e dos acampamentos, desde o início das obras da cidade. E também que houve e há uma interação entre famílias de trabalhadores migrantes e famílias goianas, nativas da região dos antigos municípios de Planaltina e Luziânia. Estabeleceram-se laços de compadrio, vizinhança, conflitos, solidariedade e amizade, que singularizaram e singularizam o Paranoá de outros contextos de Brasília (Magalhães et al., 1998).

É, assim, que Seu Galego (Sebastião Bezerra da Silva), ex-operário e agricultor, entrevistado por mim em vídeo, em 1997, expressa em palavras como se dá seu relacionamento com os goianos: 
"Eu passei a conhecer os goianos, porque a gente sempre era solteiro né, a gente trabalhava aí, naquele tempo, aí, num sei, num existia uma mulher, um cachorro. Era só os homens trabalhando né? Daí nos domingos, algum domingo que a gente tinha folga, a gente tinha aquela vontade de sair pra chácara, era aquela paixão danada, sair, só ficava naquele barulho de máquina né, aí começava a sair. Os primeiros mais perto era esse velho Sebastião. Chegava lá, encontrava com ele, conversando devagarinho com ele, né, até ir acostumando com a gente devagarinho também né, que naquele tempo eles tinham cisma desse povão, né? Ele ia acostumando com aquela calma, que ele tinha aqui quando Brasília estourou e trouxe a gente de toda parte. Eles saíam, assim, se eles viam, eles ficavam meio cabreiros, com aquele povo. É que não eram acostumados com isso. As firmas foram embora, a gente foi ficando nas terras dos goianos, goianos somos até hoje. Quando eu cheguei aqui tinha 19 anos, pra hoje eu tenho 58, já tô mais goiano que nordestino."

Esses ritmos diferentes de tempo - lentos e acelerados - acentuados na oralidade de Seu Galego, também são expressos no documentário intitulado Memórias de cá e de lá, com imagens da área urbana e área rural do Paranoá. Na ilha de edição, utilizamos recursos de aceleração de imagens de ônibus, carros, para depois desacelerar com bicicletas e caminhonetes em plano aberto na barragem, acelerando novamente e desacelerando, até um plano que se abre, de serras, horizontes e sombras das nuvens nos vales. Esse bloco termina com um plano fechado numa flor com um inseto e um travelling em pinheiros, novamente acelerando, com movimento invertido, de trás para frente.

Essa história, ocultada, só agora tornada pública, mostra-nos como grupos oprimidos desordenam, de certa forma, planos e projetos dominantes para Brasília, e forjam outras relações sociais, aí estabelecendo outros espaços absolutamente não previstos. O lugar da nova capital recebe as marcas desses homens e mulheres e também neles deixa marcas. Talvez isso nos faça entender um pouco mais porque Seu Galego, há 40 anos cultivando o sítio com sua família, hoje enfrenta injustiças e ameaças dos especuladores de terra, junto com os 
descendentes dos goianos mais pobres, antigos agricultores nativos da região.

Podemos afirmar, mesmo provisoriamente, que a história das trajetórias desses sujeitos, envolvidos na construção de Brasília e de outras localidades, expressa tempos e poderes, cheios de conteúdos, de tensões culturais, represados na memória, que não são homogêneos, que resistem. Há uma luta, um enfrentamento, quando se tenta impor a eles, pelo ouvido, falado, visto ou escrito, abstrações e linearidades que eles não comportam (Magalhães, Nunes \& Sinoti, 2000, p. 1151-2). E, em decorrência, podemos ressaltar que o registro e a interpretação, através do diálogo entre eles e o historiador, ambos considerados pensadores, não conseguem sistematizar um tempo, fora de normas e padrões, que nas suas vozes é instantâneo, múltiplo, de lembranças e esquecimentos saturados de agoras da reconhecibilidade, como um tempo suspenso do próprio tempo (cronológico), considerado o único possível.

Em várias passagens relatadas pelos sujeitos considerados neste artigo, eles experimentam um tempo que retorna, que é cíclico, em que as coisas não perecem para sempre. Há coisas que não são descartáveis, não podem ser tratadas como objetos de consumo, que devem voltar e se renovar nas estações propícias, portadoras de significação que renasce (Bosi, 1987, p. 39). Então, há uma circularidade entre passado e presente, que não é retorno dos mesmos, retorno exemplificado na reforma agrária, que José Baiano representa como lesma paralítica. Ao contrário, aquela circularidade é permanência pela transformação de um poder que não é reflexo de um outro poder dominante, porque se refere ao poder do inacabado, a uma obra que outros também, e sempre, terão que construir (Magalhães, 1996). Garantir a terra como direito de todos, como vital para a existência da própria espécie humana, é uma obra sempre por se fazer, o que é tão gritantemente esquecido nos dias de hoje, seja nas guerras, seja em algumas práticas denominadas ambientalistas.

$\mathrm{Na}$ reconstrução da memória de cada um, surgem marcas fundas, recuadas a um passado mais próximo ou mais distante, que não se apagaram ou não se apagam, porque são envoltas em sentimentos que os estimulam a prosseguir, na luta pelo enraizamento e pela terra, para que o futuro não seja perdido. Ao seu modo, cada um sugere que 
essas marcas não são impressões, isto é, reflexos de objetos exteriores. Resultam de encontros em direções oblíquas, de representações, elaboradas individualmente, com as que vêm do social, ou de outras pessoas com as quais convivem, ou conviveram; ou, ainda, com quem se sentem próximos, por identificarem fundamentos de experiências comuns.

O espaço do direito à fala, do direito à palavra pode, assim, fazer emergir práticas de sujeitos de suas próprias histórias, que também deliberam sobre os seus rumos, seus desejos de completude, segurança, proteção, aventura, como disputas de poder na sociedade, afirmando que esses devem ser direitos abertos e accessíveis a outras pessoas.

Mas esses rastros, essas pistas não se fecham a um enfrentamento com a pesquisa histórica. Pelo contrário, enriquecem-na pelo abrir de possibilidades ao historiador, quando se envolve com essas sabedorias, com esses tempos que cintilam como estrelas, que comecei a experimentar desde a minha infância, nas modelagens das matérias em oralidades, objetos, escritas, imagens... memórias e histórias.

\section{Referências bibliográficas}

ARENDT, H. Entre o passado e o futuro. São Paulo, Perspectiva, 1988.

BENJAMIN, Walter. Obras escolhidas I. Magia e técnica, arte e política. Ensaios sobre literatura e história da cultura. São Paulo, Brasiliense, 1987.

. Obras Escolhidas.Vol III. Charles Baudelaire. Um lírico no auge do capitalismo. São Paulo, Brasiliense, 1989.

FOUCAULT, Michel. Microfísica do poder. Rio de Janeiro, Graal, 1988.

GAGNEBIN, Jeanne-Marie. "Prefácio-Walter Benjamin ou a história aberta". In: BENJAMIN, Obras escolhidas I. Op. cit., p. 7-19.

GARCÍA, Wifredo Rincón. Velásquez: Grandes maestros de la pintura clásica. Editorial Estampa/Círculo de Leitores, 1996.

GONÇALVES FILHO, José Moura. "Olhar e memória". In: NOVAES, Adauto et al. O olhar. São Paulo, Cia. das Letras, 1988.

GRAMSCl, Antonio. Concepção dialética da história. Rio de Janeiro, Civilização Brasileira, 1989.

HORKHEIMER, Max \& ADORNO, Theodor W. Temas básicos de Sociologia (Org.- 
Institut für Sozialforschung, Frankfurt). São Paulo, Cultrix/Edusp, 1973.

MAGALHÃES, N. A. "Marcas da terra, marcas na terra. Um estudo da terra como patrimônio cultural e histórico". Tese de Doutorado em História Social. São Paulo: FFLCH/USP, 1996, mimeo.

. "Memória e história: diálogos entre saberes". In: Participação. Revista Dex/Unb. Brasília, n², dez. 1997, p. 36-42.

MAGALHÃES, N. A. et al. "Abrigos da memória em Brasília-DF". Projeto de pesquisa e extensão. CEAM-NECO-DEX-UnB, FAP-DF. Brasília: 1995-99. Em convênio com DePHA-SCE-GDF, a partir de 1998.

MAGALHÃES, N. A; NUNES, J. W. e SINOTI, M. L. "Del hablado, oido, escrito y visto al editado em documentales historiograficos" XI Conferencia Internacional de Historia Oral. IOHA-Internacional Oral History Association / Bogaziçi University. VOL III. Istanbul, Turquia, junho 2000, p. 1143-1152.

MAGALHÃES, N. A. "História e memória: des-cobrimentos. In: Revista do CEAM, UnB, Brasilia, $n^{\circ} 1$, julho/dezembro 2000, p. 49-56.

MAGALHÃES, N. A. e LITWINCZIK, V. "Vozes vivas ou congeladas? Tramas de lutas na história oral". In: MAGALHÃES, N.A. (org.) Cadernos CEAM- NECOIM n², UnB, Brasília, 2000, p. 13-23.

MAGALHÃES, N. A. e SINOTI, M. (org.) Memórias e direitos: moradas e abrigos em Brasilia. Brasília, NECOIM-CEAM/ DEX/UnB e SC-DePHA-GDF, 2001.

MATOS, Olgária C. F. Os arcanos do inteiramente outro. A Escola de Frankfurt. A melancolia e a revolução. São Paulo, Brasiliense, 1989. na, 1993.

MEUNIER, Mario. Nova mitologia clássica. A nova legenda dourada. História dos deuses e heróis da Antiguidade. São Paulo, Ibrasa, 1976.

THOMPSON, E. P. A formação da classe operária inglesa. Vol. I. A árvore da liberdade. Rio de Janeiro, Paz e Terra, 1987.

VEYNE, Paul Marie. Como se escreve a história. Foucault revoluciona a história. Brasília, Edunb, 1992.

Resumo: Nos limiares do século XXI, diante das incertezas e fragmentação da experiência em nossas sociedades de hoje, a memória torna-se fundamental para assegurar nossas referências como seres humanos, na construção da experiência da história. Neste trabalho, enfatizo que a história e a pesquisa histórica podem ser tecidas através de uma construção dialógica, sempre infinita, entre memórias, oralidades, escrituras, gestos, imagens, sentimentos, esquecimentos 
e lembranças de diferentes narradores e atores da sociedade. Processo que, ao evidenciar seus saberes e poderes, também os evidencia como diferentes pensadores.

PalaVRAS-CHAVE: memória; história; narrador; trama; lembrança e esquecimento.

Narrators: Voices and Powers of DifFerent Thinkers

AвSTRACT: Nowadays, in our societies, in the limits of XXI century facing the uncertainties and fragmentations of experience the memory has become an essential every day to assure the maintenance of our references as human beings, in the construction of experience and history. In this paper I intend to emphasize that history and historical research can be woven in a dialogical construction, always unfinished, among different memories, spoken and written words, gestures, images, feelings, remembrances and forgetfulness of different narrators and actors of society. That construction which expresses the narrators' powers and knowledge also expresses the narrators' roles as different thinkers.

KEYWORDS: memory; history; narrator; weaving; remembrances and forgetfulness. 